\title{
Bush Meat Trading in the Oban Hills Region of South-Eastern Nigeria: Implications for Sustainable Livelihoods and Conservation
}

\author{
Edem A. Eniang1, ; Mfonobong E. Eniang² and Clement E. Akpan³
}

\begin{abstract}
A year long markets survey of bush meat trade and consumption was organized to assess the volume and components of bush meat trade in the Oban Hills region of Cross River State, Nigeria with the specific objectives to determine (types and kinds) or species of animals (especially primates) involved in the bush meat trade and investigate their sources, quantity, prices and trends in trade as well as seasonal variations in bush meat (primate) supplies and order to determine their implications for sustainable livelihoods and conservation while creating awareness on need for sustainable harvesting and conservation of wildlife among the operators of bush meat trade and consumptive activities. Reconnaissance surveys, intensive dry and wet season markets survey using formal and informal investigative carcass examination and bargaining to inspect and price bush meat. Results show that bush meat trade is growing at an alarming rate with increasing number of hunters and traders, driven by profit motive and destructive consequences on the population of all categories of vertebrate fauna including endangered species. The paper calls for the adoption of the provisions of the Convention on Biological Diversity (CBD) of the United Nations by Nigerian government to safeguard the sustainable livelihoods and biodiversity of the nation.
\end{abstract}

\section{Introduction}

The Oban Hills region of Nigeria is home to a very diverse assemblage of primates (Schmidt 1996; Oates, 1996; Eniang and Nwufoh 2000). It is regarded as part of the continuous gulf of guinea biodiversity hotspot. The description of this ecological zone has been given by (Richards 1952; Okali 1979 and Sayer, et al, 1992). The diversity of faunal species of the region can be found in (White and Reid 1988; Reid 1989; Happold 1991 and Schmidt 1996). With increasing human population and its attendant forest resources exploitation and destruction, (NEST 1992; Olajide and Eniang 2000) many a biodiversity are exposed to varied threats to their long term survival. In the light of the above situation, (Ajayi 1994) emphasized the need for sustainable management of our biodiversity within and outside the tropical rainforest zone of Nigeria.

The declining status of African wildlife in general and primates in particular prompted the author to embark upon a bush meat trade and consumption survey to provide current and relevant data to protected area managers and policy makers for better biodiversity governance. Although several factors are responsible for the rapidly declining Wildlife population in the study area, the hunting/poaching and bush meat trade factor was chosen as the focus of this

1 Dept. of Animal, Rangeland and Wildlife Sciences, Mekelle University, P. O. Box 231,

Mekelle, Tigray Region, Ethiopia. edemeniang@yahoo.com

2. Biodiversity Preservation Center (BPC), 5 Philip Mfon close, off Parliamentary Road,

HE P. O. Box 990, Calabar, Cross River State, Nigeria.

3.Room 10,Block... Ministry of Agriculture, Idongesit Nkanga Secretariat, Uyo, Akwa Ibom State; Nigeria. Email:clemexng@yahoo.com

Acknowledgements-The authors are grateful to the Primate Society of Great Britain (PSGB) for providing Grant support for the survey. We are highly indebted to the Cross River National Park-Aking Rangers Station for providing logistic support and temporary accommodation in the Park's guest house throughout the surveys. 
research. The Oban Hills region is part of the core zone of the Cross River National Park (CRNP), Oban Division which is contiguous to the Korup National Park (KNP) of Cameroon. But the same area has witnessed rapidly growing populations of migrant farmers from several densely populated towns and cities of southern Nigeria. To achieve the set aims and objectives of the research, a year long market surveys was embarked upon to cover the major markets within the jurisdiction of the general Oban division of the CRNP, Nigeria.

In this article Bush-meat generally refers to meat from wildlife sources or undomesticated animals which are normally consumed in place of meat from domestic or livestock origin. NEST (1991) defined bush meat as the flesh of wild and undomesticated animals.

Ayodele, et al, (1999) postulated that the supply of Bush meat from wild sources no doubt serves as the only possible measure to bridge the gap between livestock production and human population growth. Wild animals of various classes and sizes, both vertebrates and invertebrates form part of the diets of people across the globe. Udo, (1999) emphasized that in Sub-Saharan Africa, the proportion of wild animal meat in total animal protein supply is exceptionally high. Asibey, et al (1990) reported that communities living near rainforests in Nigeria obtained 84 percent of their animal protein needs from Bush meat. Ajayi (1979) had shown that forest mammals accounted for between $20 \%$ and $90 \%$ of the total animal protein consumed in Benin Republic, Cameroon, Ghana, Cote d' Voire, Liberia and Nigeria. Udo, (1999) went on to show that Wild meat demands have tended to a large extent to focus on large game species such as antelopes and deer. He attributed preference to bush meat to the higher protein content and the fact that bush-meat contain less fat than domestic meat with potentials to supply iron, Vitamins A and B. The traditional inclination of rural people to bush meat is explained in (Bassey, 1999; Agom, 1997). Despite the foregoing, consumption trends have become worrisome especially when sustainable conservation of a rainforest protected area such as the CRNP is being considered. The survey was aimed at assessing the volume and components of bush meat trade in the Oban Hills region of Cross River State, Nigeria to determine (types and kinds) or species of animals involved in the bush meat trade. Efforts were made to determine their sources, quantity, prices and trends in trade as well as seasonal variations in bush-meat supplies. The paper also attempt to create awareness on need for sustainable harvesting and conservation of wildlife among the operators of bush meat trade and consumptive activities while securing their livelihoods. The human health implications of bush-meat consumption are currently a matter of emerging scientific research and calls for caution on the side of consumers.

\section{Study Area}

Oban Hills region falls approximately within Latitudes $5^{0} 15^{\prime}$ and $5^{0} 25^{\prime} \mathrm{N}$, and longitudes $8^{0} 30^{\prime}$ and $8^{0} 45^{\prime} \mathrm{E}$ of the Greenish Meridian. It is bounded in the North by the twin villages of Aking and Osomba and spreads down to Okarara village in the East. In the West, it is bounded by old Netim and Nsan villages while its Southern portion is bounded by Ekong village. Interestingly, the Oban Hills region of south eastern Nigeria is regarded as the last stronghold of the Tropical Rain Forest in Nigeria which has a significant portion in pristine condition. The area is noted for its high species diversity (White and Reid 1988; Reid 1989; Happold 1991; and Schmidt 1996). Despite these great diversity and richness, the area is prone to destruction through human activities, ranging from hunting and poaching, agriculture, logging and unguided exploitation of Non Timber Forests Products, (NTFPs) etc. The significance of Oban Forest and its ecology are well discussed by (Onochie 1979; Agboola 1979 and Nwoboshi 1982). The people of Oban are predominantly Christians and to lesser extent practitioners of African Traditional Religion (ATR). Some members of both groups are also members of several native cults such Ekpe, Ekpo and Obon. Both practitioners of African Traditional 
Religion (ATR) and Christians relish bush-meat and some make use of certain wild animal species and their body parts for worship, sacrifice and rituals while others forbid them mainly for reasons of native taboos. Interestingly, a number of people who participate in the trade in bush-meat derive their livelihoods from it and their numbers have continued to increase in recent years. The protection activities of the Cross River National Park (CRNP) project has been very significant in Oban Hills area , yet the phenomena of bush-meat consumption and trade poses in the region serious threat to sustainable wildlife conservation, with serious negative impacts upon endangered species especially.

\section{Methods}

A one week reconnaissance survey was embarked upon to familiarize with the entire area as well as determine focal points for the long term survey of the bush-meat trade in the Oban region. For this reason all local markets were explored including other trade outlets such as restaurants, bars, etc. A dry season bushmeat survey lasting for 4 Months (December- April) and covering all local markets including other trade outlets e.g. Bars, Restaurants, Bukaterias, and known trade points and routes between local towns and across the international borders with the Republic of Cameroon was undertaken with local community participants.

The same procedure used during the Dry Season Surveys was repeated in the months of May to October for rainy season Bush-meat Surveys (6 Months), to see if there existed seasonal variations in trade characteristics and components within the same focal areas. Effort was made to assess of protection and law enforcement situation of the CRNP as it concerns poaching within the Park. In this regard and recognizing that several species of wildlife are protected by State and National laws and legislations, contact visits to Rangers Station of the CRNP were organized in the study area to investigate how much protection and enforcement the park received, measures against poaching and what seizures were made and species involved. What level of awareness of conservation was existed? To obtain reliable information, the researchers employed unorthodox methods applicable to peculiar locations/community to be able to conduct certain investigative aspect of this research. The researchers made serious efforts to take video recording, coloured photographs and slides of specimens where and whenever it was possible. In most markets, the traders would not allow the use of such equipment in open markets. This was however possible when the dealers were approached individually outside the markets. The female author of this article was responsible for surveying gender sensitive bush-meat outlets which the male participants were refused access. She also posed as a potential buyer to solicit the appropriate prices.

The major trade points for bush meat in the Oban area were visited on weekly basis (Market Days) to see what was sold or traded. The researchers employed informal methods (sometimes acting as potential buyers especially in areas where bush-meat was traded in Black markets) and thus had ample opportunities to examine each specimen and bargain with the traders for the identity of the specimen, the price, and source (where it came from). The aspect of identifying each meat (species) was tackled through direct and careful observation of peculiar physical attributes of the specimen under examination (e.g. Ungulates, Primates eg Guenons, Mangabeys, Drill, Apes and/or Prosimians, Reptiles; Rodents; birds, etc). The observation of the researcher is then tested by asking the trader what meat he or she was offering for sale. The traders' response is accepted if it turns out to correspond with the researcher's observation and rejected if it does not correspond and further effort made to see the supplier to verify such response. The lead researcher having been a hunter and bush meat trader from childhood (for more than 11 years) can identify common bushmeat species of Nigeria with a high level 
of confidence. Effort were also made to have the trader mention the native name of the bush meat (animal), while the researcher made stringent effort to see fresh carcass where available and the hunter who killed the animal for the purpose of examining the head, limbs and tail, which are always retained by the hunter for his personal consumption or as a trophy if the species is adjudge very rare or strange. Smoked and dried specimens especially those prepared within the communities were traced to the homes of the dealers. Physical features such as facial and cranial formation as well as limbs and tail lengths were considered. The size and total weight of the dried carcass were assessed carefully but not recorded since the situation would not allow the use of weighing instrument. Also, most dried carcasses were embedded with several sticks (3-5) to ease the drying process as well as maintain form. All observations were noted and later recorded in field notebooks. Where bush-meat black markets were surveyed, pocket tape recorders were used anonymously to record all transactions. Furthermore, Bushmeat traders in the region are always confident and ready to tell what type of meat they were selling because of consumer preferences and prices as well as the fact that certain tribesmen do not relish certain types of animals for reasons of traditional and religious inclinations. Thus, while certain animals were considered as taboo to some tribesmen, the same animal may be highly relished by another group or tribesmen. This situation somehow places an obligation on the part of the trader to declare the true identity of the meat (animal) except when a protected species such as great apes were involved.

The researcher made contact visits to recognized hunters and ex-hunters in selected villages to verify findings, especially as it pertains to hunting grounds, methods, species involved, distribution channels and/or marketing agents particularly in Oban and Aningeje towns. Assessment of individuals' awareness of endangered species, their conservation and laws protecting them was done informally. The researcher also made arrangement for other team members to visit the same markets as potential buyers to compare information gathered. All data collected during the survey are presented in tables for ease of understanding.

\section{Results and Discussion i. Bush-meat Markets}

According to our findings and CRNP (1998 and 1999) three (3) major Bushmeat markets exist within the Oban Hills region of Nigeria namely; (a) Oban Main Market (b) Aningeje Market and (c) Mangor Bush Market. The three are weekly markets and are operated on separate days of the week since most traders patronize each of these markets as they occur weekly on rotational basis. Aningeje operates on Saturdays (5am $4.30 \mathrm{pm})$, Oban Market operates on Wednesdays (6am - 5pm) and Mangor Bush Market, which is only recently becoming popular, operates on Mondays (6.30am - 2pm). Outside Oban area but closer to Calabar is another major Bushmeat Market (Akansoko), which did not form part of the present study but may have affected the volume and pattern of bush-meat trade in the study area.

\section{ii. Trade Pattern and Species traded}

In each of these markets, full bushmeat sales do not go on throughout the duration of the markets. The present-day's strategy involves the sales of bush-meat as soon as day breaks. Here the buyers (mostly women) arrive from nearby towns of Calabar. Mfamosing and Akpabuyo of Cross River State; Uyo, Eket, IkotEkpene and Itu in Akwa Ibom State; Aba and Umuahia in Abia State and Port Harcourt, Rivers State to wait for the middlemen who will arrive the markets from hunting/poaching areas such as Mfamenyin, Ntebachot, Old Ndebiyi, Mkpots 1 and 2, and Ekonganaku (Cross River state, Nigerian villages) and Abung, Erat, Ekons 1 and 2 and Mamfe (Cameroonian villages). Also, the traders restrict the sales of bush-meat to the early (dawn) hours of the day before officials of law enforcement agencies begin their day's jobs. Movement of Bush-meat from the interior to the towns, markets, etc. are mostly effected on weekend days especially Sundays and public holidays 
when law enforcement officials are less vigilant or are off their duty post.

On most market days, the bushmeat trade will be over before $8 \mathrm{am}$ under normal circumstances. The rest of the trading for the day is basically trade on farm foodstuffs, provisions, textiles and common household wares. There are no lock-up stores or identified ware - houses. Traders are thus always mobile, moving out at the end of the days' trading with all their wares in readiness for another market day elsewhere along the trade route of Ekang border - Oban / Aningeje and Calabar. Tables 1,2,3 and 4 below shows the different species, parts and forms of presentation of the bush-meat as well as their prices in Nigerian Naira.

The research did not focus attention on other local daily, evening and weekly markets because reconnaissance surveys conducted before the actual survey in those markets did not show any significant trade in Bush-meat. This may have a lot to do with the protection activities of the CRNP in the Oban area. It's important to note that each day of the week is a potential market day including Sundays but at varying locations. Also a majority of the occupational traders patronize each of these markets by moving their wares from market to market.

The Researchers discovered that bush-meat traders were aware of the illegality of their trade yet compelled to continue, bush-meat trade being their basic means of livelihoods. The situation has caused their restriction of business to the dawn hours of market days to avoid arrests and possible persecution. It is worthy to note that many dealers could not distinguish the guenons (primates) clearly, hence the lumping together of all the guenons as a single unit in this article. The Drill stood out because it commanded higher price than other commonly traded monkeys, mainly for its uniquely sweet taste and larger size (see tables 1, 2, 3 and 4 below). It was discovered that the dealers and consumers are not necessarily disturbed about the potential health risks of bush-meat consumption in the study area.

Furthermore, the number of bulk buyers far out strips the sellers and bushmeat brought to the market, making demand very strong and leading to rising prices. Thus, each time a middleman arrives with his sacks of smoked bushmeat, the buyers struggle to get a fair share of the stock before embarking on the process of bargaining the price. Apparently, the buyers and sellers have a fairly uniform price for all the types (whole carcasses, half carcasses, fresh carcasses, partially smoked carcasses and completely smoked and dried carcasses) and for every animal species that comes to the market. Serious bargaining is only noticed when a strange animal is brought or an animal that is not commonly eaten e.g. snakes. Thus, every species e.g. Grass cutter (Thryonomis swiderianus), Brush tailed Porcupine (Atherurus africana) or Drill (Mandrillus leucophaeus) have an almost standard range of price depending on the size. A slight difference of may arise only from the bargaining power of the buyer and the resistance of the seller. The larger the number of potential buyers (increased demand), the higher will be the price of bush-meat for that moment or day.

iii Other Bush-meat trade outlets

Since most of Oban Hills region still have large forested areas, local hunters who operate in small scale around these villages are the ones who produce most of the fresh bush-meat to be found on non-market days in restaurants bars/drinking palours, roadsides, etc. As explained by an experienced hunter (Mr. Stephen) in Oban, the hunters also operated in Oban Community forest. He cited the community forests of Ekong, Osomba, Oko, Okarara, Ekonganaku and areas around the Kwa Falls, all in the present Akamkpa Local Government Area and other places in far away Cameroon.

Thus, most hunters reside in the rural areas and hunt in the areas listed above and either sells their bush-meat fresh for local consumption in the village or gives such to his wife who processes, preserves and subsequently sells it to a 
village collector (middleman), see figure 1. Aside from processing, preservation and trading, women also played significant roles in supply of inputs that sustained the vicious bush-meat trade and consumption cycle.

On the other hand, the hunter may sell directly to the middleman who will carry out the butchering, dressing, smoking and preservation (processing) of the animal into bush-meat. On other instances, the hunter sells to a roadside dealer (those who specialize on selling to travelers on major roads) who normally presents fresh animal carcasses to buyers. But if they are unable to sell them on time, they go on to process and smoke dries the animal for subsequent disposal. At other instances, some roadside dealers buy directly from a village collector, and then go on to sell this bush-meat at his usual point along the highway to maintain his customers (mostly the end consumers). Urban bush-meat dealers do not like to buy from roadside dealers who target rich urban dwellers and as such inflate their bush-meat prices. On the other hand, the urban retailer prefers to buy either directly from hunters or from middleman. In the process, there is a stiff competition among the various participants in the trade. This competition has in recent years given rise to "contract hunting", whereby an urban dealer provides either bulk cash upfront or buys the hunting inputs (shot gun, cartridges, carbide, headlamps, machetes, etc) to the hunter who in return, provides the bush-meat commensurate with the investment of the dealer. Under such arrangement, the hunter cannot sell his products to any other buyer and does not necessarily have to come to the market with his bush-meat. Contract hunters and their employers enjoy strict confidence and security if the parties involved are responsible and honour or stand by the arrangement.

Despite these seeming strong union of hunter and dealer, research has shown that often times, single (unmarried) hunters have eloped with a dealers investment to reside in another village or open a new hunting camp deep in the forest and remain there to hunt and dispose off his catch to other middlemen who collects directly from source and he does not necessarily have to come back to town to the detriment of his employer (the dealer).

Finally, "Party or gang hunting" also takes place once in a long while around Oban forest. In this case, young men form themselves into hunting party and go into the forest with well trained hunting dogs and may remain for several days hunting and preserving the products. At the end of the hunting season, they invite the village collector who buys off the products and sells directly to urban dealers who sale same at the urban markets, bars, restaurants, etc who finally sell same to the end consumers. The foregoing sequence of trade is depicted in figure 1 below and shows clearly why it is possible to obtain various kinds of bushmeat in any town in Southern Nigeria irrespective of its location or whether such animals still exist in that town or not and the ordinary observer continues to assume that wild animals are inexhaustible and are still available in their localities. It makes it difficult even for some enlightened people to accept the fact that primate and indeed many other faunal species are facing threats of extinction. The trends of trade within seasons and species involved are presented in table 1 while monthly occurrence is in table 2.

\section{iv. Park Protection}

During the surveys, efforts were made to visit some field stations of the CRNP as well as the headquarters of the park to assess aspects of protection activities. Throughout the period under study, the Park Management embarked on intensive park protection activities throughout the Oban region. The entire area was divided into 3 patrol beats; namely Ojor Ifumkpa, Iko Esai, Okokori (covering the Western axis), Nsofang cell (covering the Northern axis) and the Aking Ranger Station (covering the Eastern axis) along the Ekang Corridor including Ekonganaku all within Oban cell. It was observed that 20 Rangers and Park Wardens were responsible for the area. The Principal Park warden coordinated operations with support from Park Head Office in Akamkpa. The Oban axis received intensive patrols to check 
illegal logging, exploitation of NTFPs, Poaching and encroachment of Farms into the park.

\section{v. Problems Associated with Protection Activities in CRNP}

Unfortunately, Park Protection and surveillance operation were hampered to a large extent by logistic problems such as inadequate patrol staff, camping equipment, patrol vehicles, communication gadgets and sophisticated arms and ammunitions.

Furthermore, the surveillance operations were bedeviled with physical confrontations between Rangers and some communities especially in the Ekang Oban axis (CRNP, 1996, 1997, 1998 and 1999). In some cases, Rangers were assaulted by "Restive Youths" and Park vehicles damaged. The Park Management was not deterred and went on to seek the help of the Nigerian Police Force before the situation calmed down appreciably, while several offenders were charged to Court.

The researchers observed that the protection activities of the Park is responsible for the communities changing the bush-meat trade pattern from the usual day time sales in the late 90 s to the early dawn or day break (Black market) sales. The Ekonganaku axis which happens to be the area with the greatest volume of bushmeat that comes to Aningeje market is one of the few communities still inaccessible to rangers. Around the early 90s and middle of that decade, most community members normally pleaded ignorance of conservation laws and Park boundaries. Thus, the CRNP management went on to produce and circulate posters showing endangered animals with their vernacular names to create some levels of conservation awareness. They went on to demarcate Park boundaries with community involvement. The Park Protection activity suffered a slight set back when soldiers of Nigerian Army were moved into Oban-Ekang border region to checkmate possible Cameroonian incursions as the "cold war" over Bakassi Peninsula raged on. The presence of soldiers led to a higher human population and greater demands for space, food and other resources. Some middlemen and bush-meat dealers associated freely with the community members, soldiers, etc and often times sneaked through with their loads of bushmeat without being noticed or arrested. It is also observed that Rangers who happen to be natives of their working environment (beats) may find it difficult to enforce the laws for fear of future reprisals.

vi. Implications for Sustainable Livelihoods and Conservation

Above scenario only portends a bleak future to the sustainable future of CRNP and its rich biodiversity except urgent steps are taken to ameliorate the trend. Since the overall management of Nigerians' natural resources remains the primary assignment of the Government through its various agencies. The responsible government competent authority for wildlife conservation, the Nigerian National Parks Service (NNPS) must wake up to its responsibilities by developing strategic alternative sources of livelihoods to Parks' support zone communities so that their protective activities may be justified and sustained in the long term.

Unfortunately, many aspects of Resource development are still masterminded either by individuals, private corporations, or Government organizations. All these developmental activities, impact on the state of the environment and have contributed in different ways to environmental deterioration due mainly to absence of effective monitoring, coordination and provisions of alternative sources of livelihoods.

The Federal Government's policy goal on the conservation of biodiversity is to ensure sustainable use of forest resources and preservation of the many benefits accruing from soil, water, and wildlife conservation for economic development yet this policy does not provide alternatives to sustainable livelihoods and here lies the conflicts in Nigerian biodiversity conservation efforts. Among the current priority programmes in 
Nigeria are the extension of National Parks and Reserves and the compilation of the flora and fauna of Nigeria. Unfortunately, the crucial need for effective legislation, capacity-building, Education, Awareness creation and training has not been provided for in the plan likewise the future of the teeming populations of Parks' support zone dwellers.

NEST (1991 and 1992) shows that the Nigerian Biodiversity Strategy and Action Plan (NBSAP) reviews the status of biodiversity conservation in Nigeria in an attempt to fill the gaps identified in the country study programme, and develops strategies and action plans to bridge the gaps in the conservation effort. The first draft report for four selected eco-regions has been produced and circulated among stakeholders for their discussion and input. The actual implementations of these plans are not matched with on the ground action with stakeholders' participation but there lies the albatross of the booming illegal trade in bush-meat.

The Government's mission is that Nigeria's rich biological endowment together with the diverse ecosystems will be secured, and its conservation and management assured through appreciation and sustainable utilization by the Year 2010 but does not make provisions towards the livelihoods of affected people who hitherto depended on wildlife biodiversity and habitats for the survival. Nigeria will continue to be active in the international arena while at the local level, infra-structural, human, and institutional capabilities has to be developed to ensure equitable sharing of biodiversity benefits over time. Until such laudable plans are put into far reaching conservation action in different National Parks of the federation, bush-meat trade and consumption will continue to be the bane of Nigeria's biodiversity conservation.

\section{Conclusion and Recommendation}

Based on escalating population growth in many rural areas of Nigeria,

\section{References:}

Agboola A.A. (1979). Soils of the Nigerain Forest Zone and their Response increasing deforestation and over dependence on forest biodiversity (Bushmeat, NTFPs, etc) without recourse to the country's national biodiversity action plans, the future of the nations' rich biodiversity faces greater threats as we advance into the next decade.

Therefore, to achieve its conservation goals, the Nigerian Government's biodiversity conservation strategy which was based on: a) the inventory, identification, and rehabilitation of all threatened and endangered species of fauna and flora; b) increasing the network of protected areas to include all ecosystem types consistent with internationally accepted classification; c) promotion and enhancement measures for both in-situ and ex-situ conservation through identification, inventories, evaluation, monitoring, research, education, public awareness, and training; d) increasing the nation's biodiversity management capability (human, infrastructural, institutional, and technological); e) the development of economically and culturally sound strategies to combat biodiversity loss; f) protection and promotion of policy guidance for bio-prospecting and indigenous knowledge (intellectual property right); and g) the rehabilitation of degraded ecosystems can not work effectively without planning for affected people. Also, amiable as the goals set above appear, to date Nigeria is yet to update its national legislations to fit into the provisions of the Convention on Biological Diversity (CBD) of the United Nations for which she is a signatory nation, yet several articles (e.g. articles 7 and 8) of the convention makes adequate provisions for wildlife and humans. The adoption of the provisions of the CBD by the NNPS and updating of relevant biodiversity legislations of the country will provide the legal and legitimate basis for sustainable livelihoods and conservation of Nigerian biodiversity.

to Cultivation. In the Nigerian Rainforest Ecosystem. DUU Okali (Ed)

Ajayi, S. S. (1979). Utilization of forest wildlife in West Africa. FO/Misc. 79/26. Dec. 1979. FAO Rome. 
Agom, Damian (1997). Hunting / Poaching in the Cross River National Park (Oban Division): Against legal implications. An Msc thesis submitted to the Department of Agric Extension. University of Ibadan. Unpls.

Ajayi, S. S. (1994). Ensuring Sustainable Management of wildlife resources: the case of Africa. FAO Report, 1994, Rome.

Asibey, E. O. A. and Ghild, G. S. (1990). Wildlife Management for rural development in Sub-Saharan Africa, Unasylva 161, Vol. 41.

Ayodele, I. A., Ebin, C. O. and A. A. Alarape (1999). Essentials of wildlife management.

Bassey, P. O. E. (1999). A History of Oban with Commentary. Riverside Communications, Port Harcourt, Nigeria, pp.124.

CRNP, (1996). Cross River National Park, Akamkpa -Annual Report, 1996, Unpls.

CRNP, (1997). Cross River National Park, Akamkpa - First Quarter Report, March 1997, Unpls.

CRNP, (1998). Cross River National Park, Akamkpa - Annual Report 1998, Unpls.

CRNP, (1999). Cross River National Park, Akamkpa - Annual Report 1999, Unpls. Eniang, E. A. (1999). Confirmation of the Preuss's Red Colobus in the Rainforest of South Eastern Nigeria. American Journal of Primatology, 146:54.

Eniang, E. A. and Nwufoh, E. . (2000). Sites of Special Scientific Interest for the Conservation of Primates in Nigeria. Trans. Nig. Soc. Biol. Conserv., 7:45 - 54.
Happold, D. C. D. (1991). Large mammals of West Africa; West African Nature Handbooks, Longman. Pp $73-78$.

NEST, (1991). Nigerian Threatened Environment. A National Profile. Nigerian Environment Study/ Action Team (Nest), Ibadan.

NEST, (1992). The challenge of sustainable development in Nigeria. Tade A. Aina and Ademola. Salau (Eds). An Ngo Report prepared for the United Nations Conference on environment and Development, Rio de Janeiro, Brazil, June 10 12, 1992. pp. 247.

Oates, J. F. (1996). Revised Action Plan for African primates Conservation: 1986 1990. IUCN/SSC Primates Specialist Group, New York.

Olajide, O. and Eniang E. A. (2000). Unguided Forest Resources Exploitation and Destruction in Nigeria: Socioecological impacts. International Journal of Environment and Development. Vol. 4, No. 1. April 2000. Adulawo Publishers Ibadan. Pp.39-43.

Onochie, C. F. A. (1979). The Nigerian Rainforest Ecosystem: An Overview. In the Nigerian Rainforest Ecosystem DUU Okali (Ed.) Proceeding of the man and biosphere workshop on the Nigerian Rainforest Ecosystem. 24 - 26 January 1979. pp. 1-13.

Reid J. C. (1989). Flora and Faunal Richness of the Oban Division of the CRNP. Appendix 7 CRNP (Oban Division) Plan for Developing the Park and its support zone, WWF, Gland Switzerland. 
Figure-1. Sequence of Bush meat trade and consumption in Oban Hills region, Nigeria.

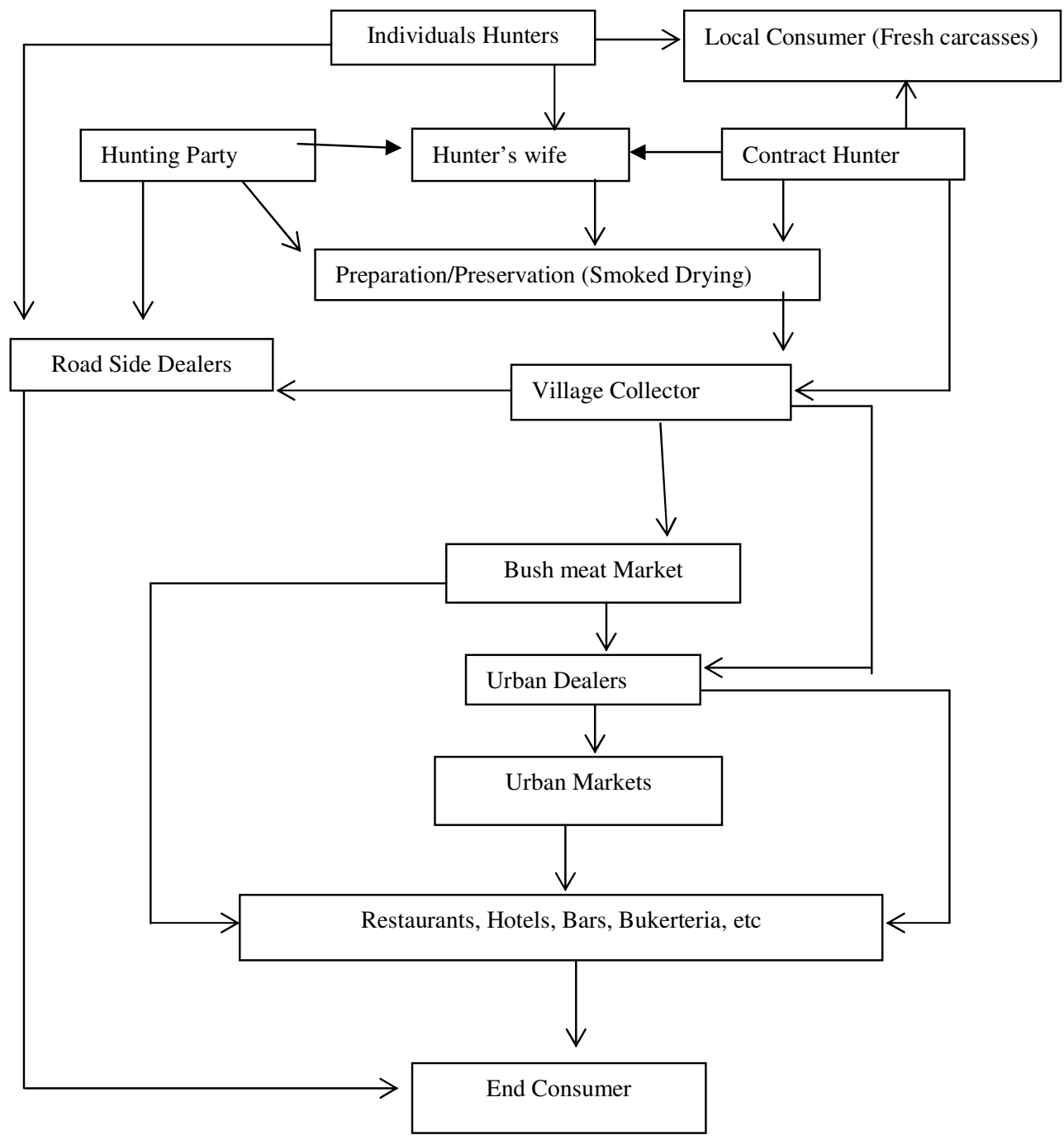


Table 1: Rainy and Dry Season Average Bushmeat Prices in Oban Region (Naira)

\begin{tabular}{|c|c|c|c|c|c|c|}
\hline $\mathbf{S} / \mathbf{N}$ & Animal/Species & $\begin{array}{l}\text { Whole } \\
\text { Males }\end{array}$ & $\begin{array}{l}\text { Whole } \\
\text { Females }\end{array}$ & $\begin{array}{l}\text { Whole } \\
\text { Males }\end{array}$ & $\begin{array}{l}\text { Whole } \\
\text { Females }\end{array}$ & Parts Removed \\
\hline 1. & Red Deer & $2,500.00$ & $2,500.00$ & $3,000.00$ & $3,000.00$ & $\begin{array}{l}\text { Head, neck, internal organs } \\
\text { and half of limbs }\end{array}$ \\
\hline 2. & Blue Duicker & 900.00 & 900.00 & $1,200.00$ & $1,200.00$ & $\begin{array}{l}\text { Head, Neck, Half of Limbs \& } \\
\text { Internal Organs }\end{array}$ \\
\hline 3. & Forest Buffalo & $18,000.00$ & $18,000.00$ & $20,000.00$ & $20,000.00$ & Internal Organs \\
\hline 4. & Drill Monkey & $4,000.00$ & $2,000.00$ & $4,500.00$ & $2,500.00$ & $\begin{array}{l}\text { Half of Limbs Internal organs } \\
\text { and head }\end{array}$ \\
\hline 5. & Chimpanzee & $6,000.00$ & $5,500.00$ & $6,500.00$ & $6,000.00$ & $\begin{array}{l}\text { Head, Limbs, Internal an sex } \\
\text { organs are sold to Hausa's for } \\
\text { rituals }\end{array}$ \\
\hline 6. & Guenons & 800.00 & 500.00 & $1,000.00$ & 800.00 & $\begin{array}{l}\text { Head, limbs, internal organs } \\
\text { \& tail }\end{array}$ \\
\hline 7. & Mangabeys & $1,000.00$ & 500.00 & $1,200.00$ & 700.00 & $\begin{array}{l}\text { Head, half of limbs, internal } \\
\text { organs and tail }\end{array}$ \\
\hline 8. & Red Colobus & 600.00 & 350.00 & 750.00 & 400.00 & $\begin{array}{l}\text { Head, limbs internal organs } \\
\text { and tail }\end{array}$ \\
\hline 9. & Grass cutter & $1,000.00$ & $1,000.00$ & $1,200.00$ & $1,200.00$ & Internal Organs \\
\hline 10. & Porcupine & 800.00 & 800.00 & $1,000.00$ & $1,000.00$ & Internal Organs \\
\hline 11. & Giant Rat* & 350.00 & 350.00 & 400.00 & 400.00 & NIL \\
\hline 12. & Mongoose* & 200.00 & 200.00 & 250.00 & 250.00 & NIL \\
\hline 13. & Bush Pig** & $6,000.00$ & $6,000.00$ & $6,500.00$ & $6,500.00$ & NIL \\
\hline 14. & Pigmy Crocodile* & $1,800.00$ & $1,800.00$ & $2,500.00$ & $2,500.00$ & NIL \\
\hline 15. & Monitor Lizard & $1,200.00$ & $1,200.00$ & $1,600.00$ & $1,600.00$ & NIL \\
\hline 16. & Python & $1,500.00$ & $1,500.00$ & $1,800.00$ & $1,800.00$ & Skin, Hemi penis, fangs \& fa \\
\hline 17. & Pangolin & $1,000.00$ & $1,000.00$ & $1,150.00$ & $1,150.00$ & Head and Internal organs \\
\hline 18. & Elephants*** & 500.00 & 500.00 & 650.00 & 650.00 & Only beef is sold \\
\hline 19. & Civet Cat & $1,200.00$ & $1,200.00$ & $1,400.00$ & $1,400.00$ & $\begin{array}{l}\text { Sexual organ, internal organs } \\
\text { skin }\end{array}$ \\
\hline 20. & Turtle* & $3,000.00$ & $3,000.00$ & $4,800.00$ & $4,800.00$ & NIL \\
\hline 21. & Tortoise & 250.00 & 250.00 & 300.00 & 300.00 & NIL \\
\hline
\end{tabular}

* $\quad$ Usually sold as whole and fresh

$* * \quad$ Usually sold whole and fresh and/or pieces because of difficulty of drying

*** $\quad$ Always sold in sizeable bits and pieces

Exchange rate 1 USD $=120$ Nigerian Naira. 
Table 2: Total Monthly Occurrence of Species in Aningeje, Oban and Mangor Markets (Dec- Oct.)

\begin{tabular}{|c|c|c|c|c|c|c|c|c|c|c|c|}
\hline SPECIES & DEC & JAN & FEB & MAR & APRIL & MAY & JUNE & JULY & AUG & SEP & OCT \\
\hline Red Deer F & 291 & 188 & 215 & 200 & 113 & 101 & 129 & 105 & 41 & 13 & 61 \\
\hline Duicker F & 300 & 291 & 188 & 257 & 168 & 215 & 190 & 88 & 69 & 101 & 136 \\
\hline Boffalo F & 9 & 4 & - & 2 & - & 1 & 2 & - & 3 & 1 & - \\
\hline Drill* $\mathrm{T}$ & 352 & 217 & 209 & 222 & 189 & 48 & 61 & 44 & 58 & 72 & 111 \\
\hline Chimps* & 5 & 2 & 2 & 1 & - & 9 & 11 & 4 & 1 & - & - \\
\hline Guenons** & 316 & 299 & 225 & 219 & 211 & 169 & 107 & 112 & 86 & 105 & 143 \\
\hline Mangabey** & 11 & 9 & 13 & 5 & - & - & 4 & 1 & 39 & 58 & 43 \\
\hline Colobus & 2 & - & - & 3 & 1 & - & - & - & - & - & - \\
\hline Grasscutter & 450 & 361 & 329 & 269 & 414 & 211 & 368 & 401 & 289 & 288 & 330 \\
\hline Porcupine B & 310 & 401 & 420 & 239 & 361 & 243 & 365 & 363 & 216 & 302 & 281 \\
\hline G/rat & - & - & - & 2 & - & - & - & 4 & - & - & 1 \\
\hline Mongoose & - & - & - & - & - & 1 & - & - & 2 & 1 & - \\
\hline Bush Pig F & 2 & - & 2 & 6 & 9 & 21 & 5 & 2 & 2 & 1 & 4 \\
\hline P. Crocodile & 4 & 2 & 1 & - & 2 & 2 & 1 & - & 1 & - & - \\
\hline M. Lizard & 6 & 2 & 12 & 4 & 1 & - & - & 1 & - & 3 & - \\
\hline Python & 2 & - & - & 3 & - & 1 & - & - & - & - & - \\
\hline Pangolin & 108 & 91 & 13 & 46 & 23 & 41 & 30 & - & 9 & 11 & 4 \\
\hline Elephant* & 1 & 1 & - & 2 & - & - & - & 1 & - & - & - \\
\hline Civet & 2 & - & - & - & - & - & 6 & 3 & 1 & 2 & 2 \\
\hline Turtle & 1 & - & 1 & - & 1 & - & - & - & - & - & - \\
\hline Tortoise & 13 & 19 & 14 & 2 & 6 & - & 1 & 1 & - & 2 & 1 \\
\hline
\end{tabular}

* - $\quad$ Each carcasses were counted as 1 irrespective to whether it was half or whole since it was not possible to link one piece of another.

** - $\quad$ Only large adult males are sold as pieces, females are sold as whole. Thus, it was easy to distinguish guenons from the larger drills.

F $\quad$ - $\quad$ These animals are always sold with their skin and fur intact.

B - - The brush at the tip of tail is left behind to distinguish the porcupine from the grasscutter.

T - $\quad$ The half limbs of the Smoked Drill bushmeat are always folded across its back before drying to support the heavy flesh of the back while the pieces of wood are placed on the anterior side. 
Table 3: Total Bush meat Found at Each Market By Species

\begin{tabular}{|c|c|c|c|c|c|c|}
\hline Species & Classification & Mangor & Oban & Aningeje & Total & $\%$ \\
\hline Sitatunga & $\begin{array}{l}\text { Tragelaphus } \\
\text { spekeii }\end{array}$ & 371 & 380 & 635 & 1,385 & 9.24 \\
\hline Duicker & $\begin{array}{l}\text { Cepholpus } \\
\text { monticola }\end{array}$ & 826 & 480 & 715 & 2,021 & 13.49 \\
\hline Buffalo & Syncerus cafer & 2 & 4 & 16 & 22 & 0.15 \\
\hline Drill & $\begin{array}{l}\text { Mandrillus } \\
\text { leucophaeus }\end{array}$ & 506 & 132 & 918 & 1,556 & 10.39 \\
\hline Chimpanzee & Pan troglodytes & 2 & 29 & 4 & 35 & 0.23 \\
\hline Guenons & Cercopithecinea & 792 & 205 & 995 & 1,992 & 13.30 \\
\hline Mangabeys & Cercocebus spp & 48 & 32 & 103 & 183 & 1.22 \\
\hline Colobus & Procolobus ssp & - & - & 6 & 6 & 0.04 \\
\hline Grasscutter & $\begin{array}{l}\text { Thryonomis } \\
\text { swiderianus }\end{array}$ & 646 & 1,128 & 1,305 & 3709 & 24.76 \\
\hline Porcupine & $\begin{array}{l}\text { Atherurus } \\
\text { africanus }\end{array}$ & 1,110 & 926 & 1,465 & 3501 & 23.36 \\
\hline $\begin{array}{l}\text { Giant pouched } \\
\text { rat* }\end{array}$ & $\begin{array}{l}\text { Crycetomis } \\
\text { gambianus }\end{array}$ & 3 & 2 & 2 & 7 & 0.05 \\
\hline Forest genet* & Genetta genetta & 1 & 1 & 2 & 4 & 0.03 \\
\hline Bush Pig & $\begin{array}{l}\text { Potamacheorus } \\
\text { spp }\end{array}$ & 8 & 14 & 32 & 54 & 0.36 \\
\hline $\begin{array}{l}\text { Pigmy } \\
\text { Crocodile }\end{array}$ & $\begin{array}{l}\text { Osteoleamus } \\
\text { tetraspis }\end{array}$ & 1 & - & 12 & 13 & 0.09 \\
\hline Monitor Lizard & $\begin{array}{l}\text { Varanus } \\
\text { niloticus }\end{array}$ & 10 & 3 & 13 & 29 & 0.19 \\
\hline Python* & Python sebae & 1 & 2 & 3 & 6 & 0.04 \\
\hline Pangolin & Manis tricuspis & 70 & 50 & 256 & 376 & 2.51 \\
\hline Elephant & $\begin{array}{l}\text { Loxodonta } \\
\text { africana }\end{array}$ & 1 & 1 & 3 & 5 & 0.03 \\
\hline Civet & $\begin{array}{l}\text { Civettictis } \\
\text { civetta }\end{array}$ & 3 & 4 & 9 & 16 & 0.11 \\
\hline Turtle & Pelusius spp & - & - & 3 & 3 & 0.02 \\
\hline \multirow[t]{2}{*}{ Tortoise } & Kinxys erosa & 9 & 19 & 31 & 59 & 0.39 \\
\hline & & & & & 14,982 & 100 \\
\hline
\end{tabular}

* Seen outside the market square but within the locality 
Table 4: Primates in Bush meat Trade in Oban Region December - October

\begin{tabular}{|c|c|c|c|c|}
\hline $\mathbf{S} / \mathbf{N}$ & English Name & Vernacular Name & Total & $\%$ \\
\hline 1. & Drill & Nsimbo & 1556 & 52.36 \\
\hline 2. & Chimpanzee & Idiok & 35 & 1.18 \\
\hline 3. & Mona Guenon & Awanda ebok & & \\
\hline 4. & Putty Nose Guenon & Ubit ebok & & \\
\hline 5. & Red Eared Guenon & Adat isim ebok & 1192 & 40.11 \\
\hline 6. & Crowned Guenon & Osobo ibuot ebok & & \\
\hline 7. & Mangabey & Ikpok ebok & 183 & 6.15 \\
\hline 8. & Red Colobus & Okoyo ebok & 6 & 0.20 \\
\hline \multirow[t]{2}{*}{9.} & Prosimians & Angwantibo/Nsama & 0 & 0 \\
\hline & & & 2972 & 100 \\
\hline
\end{tabular}

